\title{
EFFICACY OF ESSENTIAL OILS FROM BARK AND LEAF OF CINNAMOMUM ZEYLANICUM ON ROOT KNOT NEMATODE, MELOIDOGYNE GRAMINICOLA IN RICE SEEDLINGS AND YOUNG RICE PLANTS
}

\section{L.D. AMARASINGHE ${ }^{1 *}$, W.K.A.G.A. WIJESINGHE ${ }^{1}$ and B. K. JAYAWARDHANE ${ }^{2}$}

\section{${ }^{1}$ Department of Zoology, University of Kelaniya, Kelaniya, 11600, Sri Lanka ${ }^{2}$ Department of Chemistry, University of Kelaniya, Kelaniya, 11600, Sri Lanka}

\begin{abstract}
The present study was conducted to evaluate the efficacy of essential oils from leaf and bark of cinnamon, Cinnamomum zeylanicum in controlling Meloidogyne graminicola and their effects on rice seedlings and young rice plants. This study was done; to determine the $\mathrm{LC}_{50}$ of essential oils of the extracts of cinnamon leaf and bark to kill $50 \%$ of second stage juveniles $\left(\mathrm{J}_{2}\right)$ of Meloidogyne graminicola in rice root galls; to determine the efficacy of essential oils of cinnamon; in controlling $\mathrm{J}_{2}$ in rice seedlings and young rice plants; and on the growth of rice plants.

Cinnamon bark oil sample used in the current study contained about $72 \%$ cinnamaldehyde and the leaf sample contained about $86 \%$ eugenol. $\mathrm{LC}_{50}$ for cinnamon leaf oil and cinnamon bark oil for killing $50 \%$ of juveniles of $M$. graminicola in rice root galls after three days of the treatment was $0.326 \mathrm{ppm}$ and $0.454 \mathrm{ppm}$ respectively. Number of galls in the root system of nematode infested rice seedlings was significantly reduced when they were treated with $0.9 \mathrm{ppm}$ of cinnamon leaf oil and bark oil compared to untreated controls. However, the nematicidal activity between the cinnamon leaf oil and bark oil was not significantly different. The root gall index of infested young rice plants was significantly lowered when they were treated with either cinnamon leaf oil or bark oil compared to untreated controls. It was revealed that the mean plant height and the mean number of roots of essential oil treated plants were positively correlated with the number of root galls whereas, the number of dead plants and the mean percentage chlorosis were negatively correlated. Nevertheless, the mean root length did not show any significant correlation with number of root galls. This study concludes that essential oils of cinnamon
\end{abstract}

\footnotetext{
* Corresponding author: Email: deepika@kln.ac.lk
} 
leaf which contained $86 \%$ eugenol and bark which contained $72 \%$ cinnamaldehyde are similarly effective in suppression of $M$. graminicola in rice seedlings and young rice plants. According to the rates of application of essential oils of cinnamon leaf and bark, none of them have significant negative effect on the plant growth. Hence, they can be used as an alternative nematicide against the rice root knot nematode, $M$. graminicola in early stage of rice plants.

Keywords: Cinnamomum zeylanicum; essential oils; Meloidogyne graminicola;Oryza sativa

\section{INTRODUCTION}

Meloidogyne graminicola (L. Golden and Birchfield) is recorded as a pest of rice,Oryza sativa in Sri Lanka (Ekanayake \& Toida, 1997, Anon, 2001; Nugaliyadde et al., 2001; Amarasinghe et al., 2007). Nugaliadde et al., 2001 reported that there is a yield loss due to this nematode species when more than $75 \%$ of the root system of the plant is infested.

The characteristic damage symptoms of $M$. graminicola are the enlargement of roots and formation of hooked like galls in the root tips of infested plants. They cause arrestment of root growth. Usually, there are no distinct symptoms on foliage of affected plants unless the nematode infestation becomes severe. In very severe cases, newly emerged leaves appear distorted and dried up along the margins and chlorosis can be seen. Infested plants show stunting growth resulting of a considerable yield loss (Ou, 1985). Integrated nematode management is the widely recognized method of controlling the Meloidogyne species (Bridge \& Aploeright, 2005; Whitehead, 1998; Amarasinghe et al., 2007) that aim to prevent further distribution of the nematode and to decrease the yield loss. In Sri Lanka, suppression of $M$. graminicola has been achieved with varying success by integrating a number of physical, chemical, and cultural measures that introduced by the Department of Agriculture, Sri Lanka (Anon., 2001).

In later years, several authors have demonstrated to use essential oils and their components from variety of plant species as alternative bio control agents against plant parasitic nematodes (Abbas et al., 2009; Choi et al., 2007; Kong et al., 2007; Albuquerque et al., 2007). The present study was carried out to determine the efficacy of essential oils of leaf and bark of Cinnamomum zeylanicum on the second stage juveniles of M. graminicola and their effects on rice seedlings and young rice plants. 


\section{MATERIALS AND METHODS}

\section{Source of Meloidogyne graminicola inoculum}

Identification of Meloidogyne graminicola was done to the species level using the characteristic cuticular pattern that surrounds the vulva and anus of the adult female nematodes (Taylor \& Netscher, 1974). Infested rice plants were maintained in a $36 \mathrm{~cm}$ diameter and $18 \mathrm{~cm}$ deep plastic basin half filled with moisten de-faunated soil to raise the nematode population. The root galls positive for nematodes and active juveniles collected from them were used for experiments.

\section{Extraction of essential oils from bark and leaf of cinnamon, Cinnamomum zeylanicum}

A 40g sample of plant material, cinnamon bark and cinnamon leaf, was treated with a $1 \%$ solution of cellulase and $1 \%$ pectinase enzyme and incubated with $50 \mathrm{ml}$ of $\mathrm{pH}$ 7.4, $0.05 \mathrm{M}$ phosphate buffer for 14 days separately. After the incubation period, the plant material was transferred to two flasks and essential oils were extracted separately for $3 \mathrm{~h}$ using steam distillation. A $1 \mu \mathrm{l}$ of each sample was analyzed using Hewlett Packard gas chromatograph (Model 5890) equipped with a FID detector (Flame Ionization Detector). Gas chromatography profile was compared with reported values. Cinnamon bark oil sample used in the current study contained about $72 \%$ cinnamaldehyde and the leaf sample contained about $86 \%$ eugenol. $0.5 \mu 1$ of Tween- 20 was used to dissolve $1 \mu 1$ of cinnamon oils. Concentrations of essential oils were prepared using serial dilution with distilled water.

Experiment I: Screening the effect of different concentrations of cinnamon leaf oil and bark oil on $\mathbf{J}_{\mathbf{2}}$ of Meloidogyne graminicola in the laboratory.

$5 \mathrm{ml}$ each from 0.01, 0.03, 0.1, 0.3 and $0.9 \mathrm{ppm}$ of cinnamon leaf oil and 0.1, 0.3, and $0.9 \mathrm{ppm}$ of cinnamon bark oil were added separately into cleaned petri dishes each measuring $5 \mathrm{~cm}$ diameter. Each concentration was replicated 10 times. $5 \mathrm{ml}$ each of $0.5 \mu \mathrm{l}$ Tween-20 and distilled water were added separately into 10 petri dishes each and they were used as two sets of controls. Three root galls each expected to contain about 70 juveniles of M. graminicola were introduced into each petri dish. Closed Petri dishes were arranged in a complete randomized design at $26 \pm 2{ }^{\circ} \mathrm{C}$ room temperature. Three days after inoculation, root galls were teased individually and all $\mathrm{J}_{2}$ stage nematodes were counted on a sedgewick rafter cell held under the microscope with $10 \times 10$ magnification. 
Nematodes were confirmed as dead if they were motionless to a mechanical pricking and their bodies held straight after transferring them to distilled water.

\section{Experiment II: Screening the effect of cinnamon leaf oil and bark oil on Meloidogyne graminicola in seedling rice.}

Approximately 250 rice seeds were washed well with $0.5 \mathrm{mgl}^{-1}$ potassium permanganate and then rinsed thoroughly with distilled water. They were equally spread on fifteen wetted filter papers each of $9 \mathrm{~cm}$ diameter. They were laid on the bottom of fifteen plastic containers each with $9 \mathrm{~cm}$ diameter and $6 \mathrm{~cm}$ height. Seeds were maintained until they are germinated in the laboratory. After one week, well grown 10 seedlings were allowed to remain in each pot and others were removed. Ten $\mathrm{ml}$ each of the following treatments were given separately into five containers and the treatments were replicated three times. $\mathrm{T}_{1}$. Distilled water with 100 juveniles; $\mathrm{T}_{2}$ - $0.9 \mathrm{ppm}$ cinnamon leaf oil with 100 juveniles; $\mathrm{T}_{3}$ - 0.9 ppm cinnamon bark oil with 100 juveniles; $\mathrm{T}_{4}$ - Distilled water only; $\mathrm{T}_{5}$ 0.5 ppm Tween-20 only. After one week of the treatment, a soil solution was added into each container to maintain the growth of the seedlings. Seedlings were allowed to remain for one more week in same containers to deploy the root system. The plants were then removed from containers and the number of root galls due to nematodes in each seedling was counted separately.

\section{Experiment III: Screening the effect of cinnamon leaf oil and bark oil on Meloidogyne graminicola in potted rice plants}

Twenty eight plastic containers $(9 \mathrm{~cm}$ diameter and $6 \mathrm{~cm}$ height) were filled with moisten de-faunated soil up to $1 / 3$ each of it. Rice plants at the rate of ten plants per container were maintained for two weeks from germination. Calculated amounts of NPK fertilizer was added into each pot as recommended by the authority of the Department of Agriculture, Sri Lanka. Four pots were given $10 \mathrm{ml}$ of one of the following treatments. $\mathrm{T}_{1}$ Distilled water with 100 juveniles; $\mathrm{T}_{2}-0.9 \mathrm{ppm}$ leaf oil with 100 juveniles; $\mathrm{T}_{3}-0.9 \mathrm{ppm}$ bark oil with 100 juveniles; $\mathrm{T}_{4}$ - Distilled water; $\mathrm{T}_{5}$ - $0.9 \mathrm{ppm}$ cinnamon leaf oil; $\mathrm{T}_{6}-0.9 \mathrm{ppm}$ cinnamon bark oil; $\mathrm{T}_{7}-0.5 \mathrm{ppm}$ Tween-20. Pots were maintained in a completely randomized design outside the laboratory. The height of the plant, the number of dead leaves, the number of roots, the length of roots, and the number of root galls in each plant and the number of dead plants in each pot, were recorded after three weeks from inoculation. 


\section{Data Analysis}

Data were corrected for control mortality using Abbott's formula (Abbott, 1925). The $\mathrm{LC}_{50}$ values were calculated by profit values of adjusted mean percentage mortality (Minitab version 14). Data were subjected to analysis of variance including Least Significant Difference (LSD) and Duncan's multiple Range Test (Sokal and Rohlf, 1995).

\section{RESULTS AND DISCUSSION}

\section{Experiment I: Screening the effect of different concentrations of cinnamon leaf and bark oil on $\mathrm{J}_{2}$ of Meloidogyne graminicola in the laboratory}

Figure 1 shows the adjusted percentage mortality of $\mathrm{J}_{2}$ stage of $M$. graminicola against different concentrations of cinnamon leaf oil and bark oil. It indicates that the highest mortality of the nematode was in $0.9 \mathrm{ppm}$ of both cinnamon leaf oil and bark oil. There was no significant difference in the nematode mortality between two concentration levels of leaf oil namely $0.3 \mathrm{ppm}$ and $0.9 \mathrm{ppm}$. However, the nematode mortality was significantly different between $0.1 \mathrm{ppm}$ and $0.9 \mathrm{ppm}$ leaf oil $(\mathrm{p}=0.001, \mathrm{t}=3.89, \mathrm{df}=19)$. Figure 2 envisages that the $\mathrm{LC}_{50}$ for cinnamon leaf oil is $0.326 \mathrm{ppm}$ and bark oil for $50 \%$ mortality of $\mathrm{J}_{2} M$. graminicola is $0.454 \mathrm{ppm}$ (Figure 3). It is envisaged from $\mathrm{LC}_{50}$ values that the concentration of cinnamon leaf oil required to kill $50 \%$ of $\mathrm{J}_{2} \mathrm{M}$. graminicola is lower than that of cinnamon bark oil. However, there is no significant difference between the percentage mortality of $J_{2}$ in respective concentrations of cinnamon leaf oil and cinnamon bark oil $(\mathrm{p}=0.819, \mathrm{df}=1)$.

\section{Experiment II: Screening the effect of cinnamon leaf oil and bark oil on Meloidogyne graminicola in seedling rice}

Table 1 shows the mean number of root galls in cinnamon leaf oil treated and cinnamon bark oil treated seedlings at the end of the experiment. The number of root galls were significantly lowered in the cinnamon leaf oil treated rice plants $(\mathrm{p}=0.033, \mathrm{t}=-2.38$, $\mathrm{df}=13)$ and cinnamon bark oil treated rice plants $(\mathrm{p}=0.01, \mathrm{t}=-3.24, \mathrm{df}=9)$ compared to untreated controls. However, the differences of gall formation are not significant between two essential oils $(\mathrm{p}=0.24, \mathrm{t}=-1.24, \mathrm{df}=12)$. 


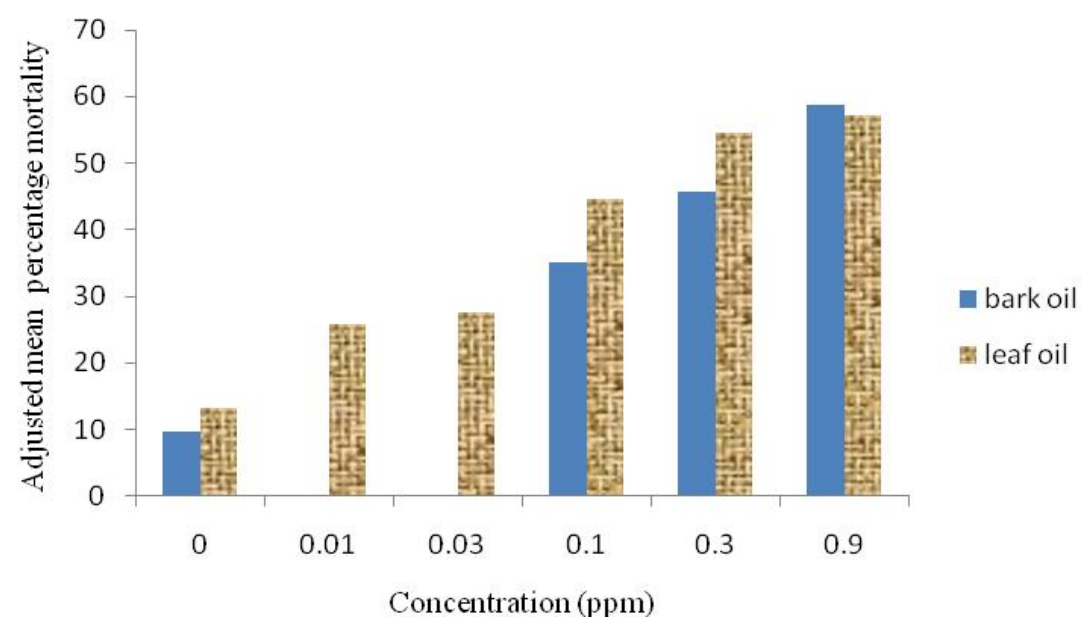

Figure 1: The adjusted percentage mortality $( \pm \mathrm{SE})$ of second stage juveniles of $M$. graminicola against the different concentrations of cinnamon leaf oil after three days of treatment.

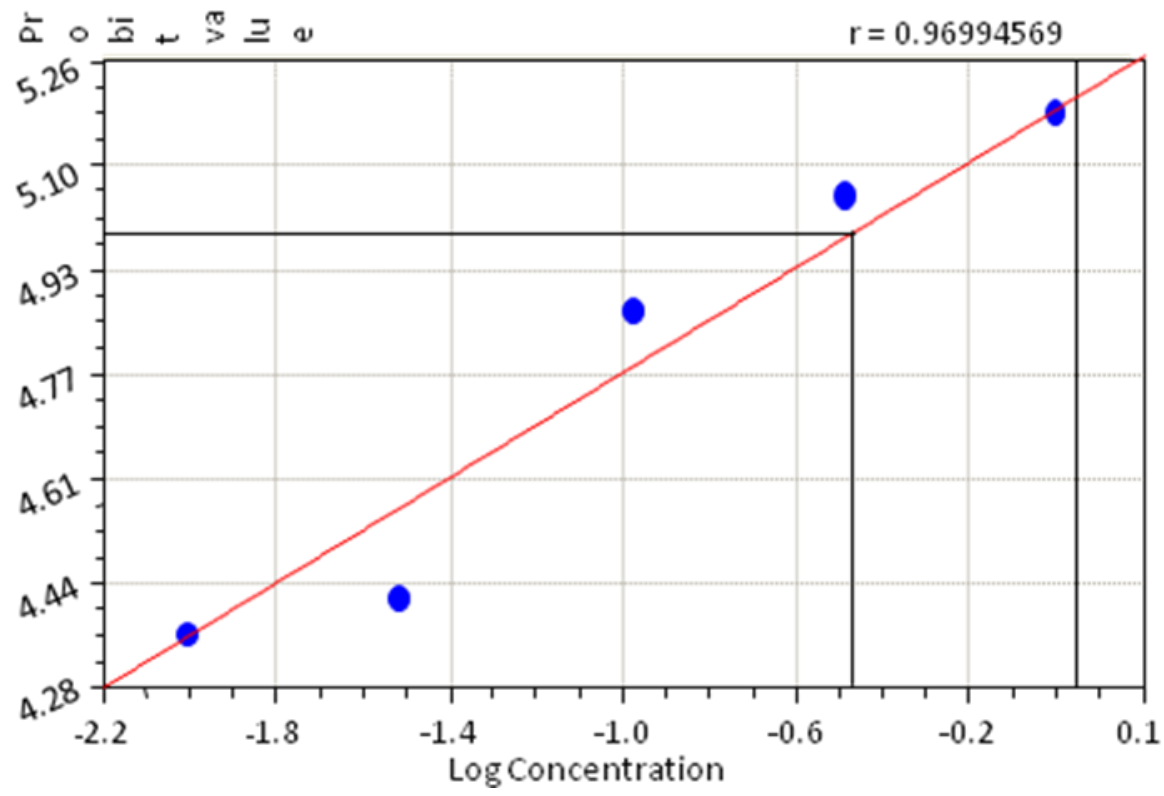

Figure 2: Probit values of adjusted percentage mortality of $J_{2}$ against log concentration of cinnamon leaf oil 


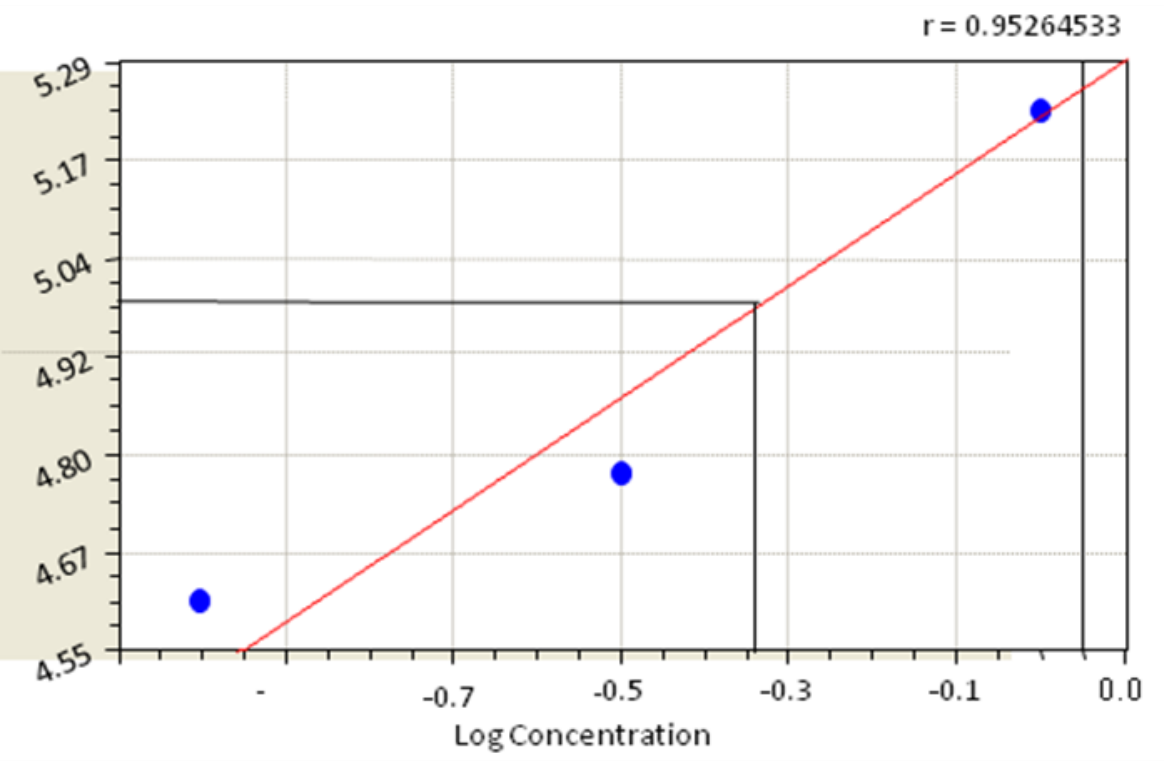

Figure 3: Probit values of adjusted percentage mortality of $J_{2}$ against $\log$ concentration of cinnamon bark oil

Table 1: Mean total root galls in cinnamon leaf oil and cinnamon bark oil treated seedlings

\begin{tabular}{ll}
\hline Treatment & Mean total root galls $( \pm$ SE) \\
\hline Distilled water + juveniles (untreated) & $16.0 \pm 0.4^{\mathrm{a}}$ \\
$0.9 \mathrm{ppm}$ leaf oil + juveniles & $4.0 \pm 0.2^{\mathrm{b}}$ \\
$0.9 \mathrm{ppm}$ bark oil + juveniles & $1.0 \pm 0.1^{\mathrm{b}}$ \\
Distilled water & 0 \\
$0.5 \mathrm{ppm}$ Tween-20 & $1.0 \pm 0.1^{\mathrm{b}}$ \\
\hline
\end{tabular}

Experiment III: Screening the effect of cinnamon leaf oil and bark oil on Meloidogyne graminicola in potted rice plants

It was observed that the percentage chlorosis and mean number of dead plants have been increased in pots treated only with second stage juveniles (Table 2) $(\mathrm{p}=0.003, \mathrm{~F}=$ 6.58). However, the mean plant height did not show and significant difference between treatments. This is indicative that there is no significant phyto-toxicity due to cinnamon leaf oil or Tween-20 on rice plants. The root gall formation was significantly reduced in 
cinnamon leaf oil treated rice plants $(\mathrm{n}=8.5 \pm 0.13 ; \mathrm{p}=0.002, \mathrm{t}=3.34$, $\mathrm{df}=45)$ and bark oil treated plants $(\mathrm{n}=8.3 \pm 0.12 ; \mathrm{p}=0.000, \mathrm{t}=5.64, \mathrm{df}=45)$ compared to untreated plants $(\mathrm{n}=16.1 \pm 1.6)$. However, the gall indices between cinnamon leaf oil treated rice plants and cinnamon bark oil treated rice plants was not significant $(\mathrm{p}=0.218, \mathrm{~F}=1.89)$. An increased number of dead plants, the lowest plantheight and the highest chlorosis were observed in the plants treated only with nematode juveniles. However, neither the dead plants $(\mathrm{p}=0.441, \mathrm{~F}=0.82)$ nor plant height $(\mathrm{p}=0.054, \mathrm{~F}=0.82)$ was significantly different among treatments.

Table 2: Post-treatment measurements of cinnamon leaf oil treated young rice plants $( \pm \mathrm{SE})$

\begin{tabular}{lllllll}
\hline Treatment & $\begin{array}{l}\text { Mean \% } \\
\text { dead plants }\end{array}$ & $\begin{array}{l}\text { Mean } \\
\text { plant } \\
\text { height }\end{array}$ & $\begin{array}{l}\text { Mean \% } \\
\text { chlorosis }\end{array}$ & $\begin{array}{l}\text { Mean No. } \\
\text { of roots }\end{array}$ & $\begin{array}{l}\text { Mean } \\
\text { root } \\
\text { length }\end{array}$ & $\begin{array}{l}\text { Mean No. } \\
\text { of galls }\end{array}$ \\
\hline Distilled water $+\mathrm{J}_{2}$ & $20.0 \pm 7.1^{\mathrm{ab}}$ & $14.4 \pm 1.1^{\mathrm{b}}$ & $62.5 \pm 6.7 \mathrm{a}$ & $7.2 \pm 0.7$ & $4.9 \pm 0.51$ & $16.1 \pm 1.6^{\mathrm{a}}$ \\
0.9 ppm leaf oil $+\mathrm{J}_{2}$ & $32.5 \pm 4.7^{\mathrm{a}}$ & $15.4 \pm 0.7^{\mathrm{ab}}$ & $59.1 \pm 4.6^{\mathrm{ab}}$ & $6.9 \pm 0.6$ & $5.4 \pm 0.54$ & $8.5 \pm 0.1^{\mathrm{b}}$ \\
0.9 ppm bark oil $+\mathrm{J}_{2}$ & $25.0 \pm 0.5^{\mathrm{a}}$ & $19.9 \pm 1.1^{\mathrm{ab}}$ & $49.5 \pm 7.2^{\mathrm{ab}}$ & $10.1 \pm 0.8$ & $6.7 \pm 0.58$ & $8.3 \pm 0.1^{\mathrm{b}}$ \\
Distilled water & $20.0 \pm 2.1^{\mathrm{ab}}$ & $21.2 \pm 5.4^{\mathrm{a}}$ & $43.2 \pm 5.4^{\mathrm{b}}$ & $7.2 \pm 0.3$ & $5.1 \pm 0.5$ & 0 \\
0.9 ppm leaf oil & $5.5 \pm 3.7^{\mathrm{c}}$ & $15.4 \pm 0.9^{\mathrm{ab}}$ & $42.5 \pm 2.8^{\mathrm{b}}$ & $7.2 \pm 0.3$ & $4.7 \pm 0.16$ & 0 \\
0.9 ppm bark oil & $15.0 \pm 1.4^{\mathrm{b}}$ & $16.4 \pm 1.5^{\mathrm{ab}}$ & $44.6 \pm 2.9^{\mathrm{b}}$ & $9.2 \pm 1.3$ & $5.5 \pm 0.34$ & 0 \\
0.5 ppm Tween-20 & $17.5 \pm 2.7^{\mathrm{b}}$ & $17.3 \pm 0.4^{\mathrm{ab}}$ & $28.1 \pm 2.9^{\mathrm{c}}$ & $8.6 \pm 0.4$ & $5.4 \pm 0.39$ & 0
\end{tabular}

Data indicated by the same letters are not significantly different at $\mathrm{p}=0.05$ according to Duncan's multiple range test.

These results show that the essential oils of cinnamon have shown nematicidal activity. Studies conducted on the effectiveness of the cinnamon oil on the stored grain insects, fungal pests and nematodes have also shown the potential of these botanicals as replacement for synthetic insecticides (Paranagama et al., 2003, Kong et.al, 2007). In a detailed study have shown a higher nematicidal activity of trans-cinnamaldehyde against the Meloidogyne javanica (Oka, 2001). This study further reports that $\mathrm{EC}_{50}$ value of transcinnamaldehyde for juvenile immobilization and hatching inhibition in vitro were as low as $15 \mu \mathrm{l} / 1$ and $11.3 \mu \mathrm{l} / \mathrm{l}$ respectively. In a micro plot experiment, soil treatment with transcinnamaldehyde $\left(50 \mathrm{ml} / \mathrm{m}^{2}\right)$ has caused a reduction of the galling index and has increased the shoot weight of tomato plants (Oka, 2001). Galling incidence and size of the gall are dependent upon nematode density and the nematode species. In the present study, the 
number of root galls has been considered as an index of the nematode population. The root gall formation in rice seedlings and young rice plants due to $M$. graminicola was significantly reduced in the treated plants with cinnamon leaf oil and cinnamon bark oil. None of the treatments, cinnamon leaf oil, cinnamon bark oil or Tween-20 showed a significant phytotoxicity in rice plants. Cinnamon leaf oil and cinnamon bark oil can be used as an environmental friendly nematicide against the rice root knot nematode Meloidogyne graminicola in rice seedlings and in young rice plants.

\section{CONCLUSIONS}

$\mathrm{LC}_{50}$ for cinnamon leaf oil for killing $50 \%$ of juveniles of $M$. graminicola in rice root galls after three days of the treatment was $0.326 \mathrm{ppm}$ and that for cinnamon bark oil was $0.454 \mathrm{ppm}$.

Nematicidal activity is not significantly different between cinnamon leaf oil and bark oil.

Concentration of $0.9 \mathrm{ppm}$ of cinnamon leaf oil and bark oil is required to reduce the formation of root galls in rice plants infested with M. graminicola.

\section{REFERENCES}

Abbas S., S. Dawar, M. Tariq \& M.J. Zaki. 2009. Nematicidal activity of spices against Meloidogyne javanica (Treub) Chitwood. Pakistan Journal of Botany 41(5): 26252632.

Abbot W.S. 1925. A method for computing the effectiveness of an insecticide. Journal of Economic Entomology 18: 265-267.

Albuquerque M.R., J.R. Costa, S.M.O. Bandeira, P.N. Santiago, G.M.P. Andrade-Nept, M. R. Silveriae \& O.D.L Pessoa. 2007. Nematicidal and larvicidal activities of the essential oils from aerial parts of Pectis oligocephala and Pectis apodocephala Baker. Annals of the Brazilian Academy of Sciences 79 (2): 209-213.

Amarasinghe L.D., K.A.D.P.S. Kariyapperuma \& H.N.I. Pathirana 2007. Study on approaches to integrated control of Meloidogyne graminicola in rice. Journal of Science of the University of Kelaniya, Sri Lanka 3: 29-46.

Anon. 2001. Department of Agriculture at the turn of the century. The Department of Agriculture, Peradeniya, Sri Lanka. 164 pp.

Bridge J.M., \& Aploeright 2005. Nematode parasites of rice. In, Plant parasitic nematodes in tropical and subtropical agriculture. $2^{\text {nd }}$ edition (M. Luc, R.A. Sikora, J. Bridge, Eds), C.A.B. International Wallingford. UK. 87-130 p. 
Choi I.H., J.Y. Park, S.C. Shin, J. Kim \& I.K. Park 2007. Nematicidal activity of medicinal plant essential oils against the pinewood nematode (Bursaphelenchus xylophilus). Applied Entomology \& Zoology 42 (3): 397-401.

Ekanayake H.M.R.K. \& Y. Toida 1997. Nematode parasites of Agricultural crops and their distribution in Sri Lanka. JIRCA Journal 4: 23-29.

Kong J.O., S.M. Lee, Y.S. Moon, S.G. Lee \& Y.J. Ahn 2007. Nematicidal activity of cassia and cinnamon oil compounds and related compounds toward Bursaphelenchus xylophilus (Nematoda: Parasitaphelenchidae). Journal of Nematology 39(1): 31-36.

Nugaliyadde L., D.M.N. Dissanayake, H.M.D.N. Herath, C.M.D. Dharmasena \& D.M. Jayasundara 2001. Outbreak of rice root knot nematode, Meloidogyne graminicola (Golden \& Birchfield) in Nikewaratiya, Kurunegala in Maha 2000/2001. Short Communication. Annals of the Sri Lanka Department of Agriculture 3: 373-374.

Oka Y. 2001. Nematisidal activity of essential oil components against the root-knot nematode Meloidogyne javanica. Nematology 3: 159-164.

Ou S.H. 1985. Rice diseases ( $2^{\text {nd }}$ edition). CAB International publication,UK. 358 pp.

Paranagama P.A., T. Abeysekera, L. Nugaliyadde \& K.P. Abeywickrema 2003. Effect of the essential oils of Cymbopogon citratus, $C$. nardus and Cinnamomum zeylanicum on pest incidence and grain quality of rough rice (paddy) stored in an enclosed seed box. Annals of Sri Lanka Food, Agriculture and Environment 1(2): 134-136.

Sokal R. \& F.J. Rohlf 1995. Biometry: The principals and Practices of Statistical in Biological Research. Freeman, New York. 887 pp.

Taylor D.P. \& C. Netcher 1974. An improved technique for preparing perennial pattern of Meloidogyne spp. Nematologica 20(2): 268-269.

Whitehead A.G. 1998. Plant nematode control. CAB International, New York. 230 pp. 